\title{
Article \\ Chemical Composition, In Vitro and In Situ Antimicrobial and Antibiofilm Activities of Syzygium aromaticum (Clove) Essential Oil
}

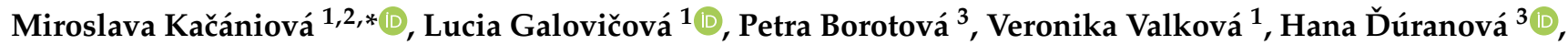 \\ Przemysław Łukasz Kowalczewski $\left.{ }^{4}{ }^{(}\right)$, Hussein A. H. Said-Al Ahl ${ }^{5}$, Wafaa M. Hikal ${ }^{6,7}$, Milena Vukic ${ }^{8}{ }^{(D}$, \\ Tatsiana Savitskaya ${ }^{9}$, Dzmitrij Grinshpan ${ }^{9}$ and Nenad L. Vukovic ${ }^{8, *}$
}

Citation: Kačániová, M.; Galovičová, L.; Borotová, P.; Valková, V.; Dúranová, H.; Kowalczewski, P.Ł.; Said-Al Ahl, H.A.H.; Hikal, W.M.; Vukic, M.; Savitskaya, T.; et al. Chemical Composition, In Vitro and In Situ Antimicrobial and Antibiofilm Activities of Syzygium aromaticum (Clove) Essential Oil. Plants 2021, 10, 2185. https://doi.org/10.3390/ plants10102185

Academic Editor: Petko Denev

Received: 19 September 2021

Accepted: 13 October 2021

Published: 15 October 2021

Publisher's Note: MDPI stays neutral with regard to jurisdictional claims in published maps and institutional affiliations.

Copyright: (c) 2021 by the authors. Licensee MDPI, Basel, Switzerland. This article is an open access article distributed under the terms and conditions of the Creative Commons Attribution (CC BY) license (https:// creativecommons.org/licenses/by/ $4.0 /)$.
1 Institute of Horticulture, Faculty of Horticulture and Landscape Engineering, Slovak University of Agriculture, Tr. A. Hlinku 2, 94976 Nitra, Slovakia; 1.galovicova95@gmail.com (L.G.); veronika.valkova@uniag.sk (V.V.)

2 Department of Bioenergy, Food Technology and Microbiology, Institute of Food Technology and Nutrition, University of Rzeszow, 4 Zelwerowicza Str., 35-601 Rzeszow, Poland

3 AgroBioTech Research Centre, Slovak University of Agriculture, Tr. A. Hlinku 2, 94976 Nitra, Slovakia; petra.borotova@uniag.sk (P.B.); hana.duranova@uniag.sk (H.Ď.)

4 Department of Food Technology of Plant Origin, Poznań University of Life Sciences, 31 Wojska Polskiego Str., 60-624 Poznań, Poland; przemyslaw.kowalczewski@up.poznan.pl

5 Medicinal and Aromatic Plants Research Department, National Research Centre, 33 El-Bohouth Str., Dokki, Giza 12622, Egypt; shussein272@yahoo.com

6 Department of Biology, Faculty of Science, University of Tabuk, P.O. Box 741, Tabuk 71491, Saudi Arabia; wafaahikal@gmail.com

7 Water Pollution Research Department, Environmental Research Division, National Research Centre, 33 El-Bohouth Str., Dokki, Giza, 12622, Egypt

8 Department of Chemistry, Faculty of Science, University of Kragujevac, 34000 Kragujevac, Serbia; milena.vukic@pmf.kg.ac.rs

9 Research Institute for Physical Chemical Problems, Belarusian State University, Leningradskaya Str. 14, 220030 Minsk, Belarus; savitskayaTA@bsu.by (T.S.); grinshpan@bsu.by (D.G.)

* Correspondence: miroslava.kacaniova@gmail.com (M.K.); nvchem@yahoo.com (N.L.V.)

Abstract: The essential oil of Syzygium (S.) aromaticum (CEO) is known for its good biological activity. The aim of the research was to evaluate in vitro and in situ antimicrobial and antibiofilm activity of the essential oil produced in Slovakia. The main components of CEO were eugenol $82.4 \%$ and (E)-caryophyllene $14.0 \%$. The antimicrobial activity was either weak or very strong with inhibition zones ranging from 4.67 to $15.78 \mathrm{~mm}$ in gram-positive and gram-negative bacteria and from 8.22 to $18.56 \mathrm{~mm}$ in yeasts and fungi. Among the tested bacteria and fungi, the lowest values of MIC were determined for Staphylococcus (S.) aureus and Penicillium (P.) expansum, respectively. The vapor phase of CEO inhibited the growth of the microscopic filamentous fungi of the genus Penicillium when tested in situ on bread. The strongest effect of mycelia inhibition in a bread model was observed against $P$. expansum at concentrations of 250 and $500 \mu \mathrm{L} / \mathrm{mL}$. The best antimicrobial activity of CEO in the carrot model was found against $P$. chrysosenum. Differences between the mass spectra of Bacillus (B.) subtilis biofilms on the tested surfaces (wood, glass) and the control sample were noted from the seventh day of culture. There were some changes in mass spectra of Stenotrophomonas (S.) maltophilia, which were observed in both experimental groups from the fifth day of culture. These findings confirmed the impact of CEO on the protein structure of older biofilms. The findings indicate that, besides being safe and sensorially attractive, S. aromaticum has antimicrobial activity, which makes it a potential substitute for chemical food preservatives.

Keywords: Syzygium aromaticum; in vitro; in situ; antimicrobial activity; antibiofilm activity 


\section{Introduction}

Syzygium aromaticum is known for its use as spice in the preparation of food. Besides being valued for its flavoring properties, it can be used as an anti-cancer agent and a traditional remedy for many diseases such as asthma; digestive system, dental, and respiratory disorders; headaches; and sore throats [1]. It is also used in traditional medicine. Clove is widely used for treating dyspepsia, gastritis, and diarrhea. Furthermore, it was found that it has antipyretic, aphrodisiac, appetizing, expectorant, antiemetic, anxiolytic, myorelaxant, analgesic, decongestant, anti-inflammatory, and hypnotic effects [2]. The essential oil of $S$. aromaticum also shows anti-inflammatory, cytotoxic, and anesthetic activities besides the reported antimicrobial, antifungal, antiviral, antioxidant, and insecticidal properties [3].

The phenylpropene eugenol is the most important clove component. It is responsible for the characteristic strong aroma [4]. Inhibition of molds, yeast, and bacteria is one of the possible applications of clove essential oil [5]. The clove essential oil was proven to have repressing effects on some microorganisms such as Alternaria spp., Aspergillus spp., Canninghamella spp., Lactobacillus spp., Fusarium spp., Clostridium spp.; Mucor spp., Salmonella spp., Penicillium spp., and Bacillus spp. [6].

While being safe, non-toxic, and biodegradable, clove essential oil (CEO) shows a broad-spectrum antibacterial activity and can thus be used as bacteriostatic and antibiofilm agent. Budri et al. [7] reported that CEO has significant inhibitory effect on biofilm. Rajkowska et al. [8] confirmed the inhibition of Candida biofilm on the surface of different materials by CEO. Adil et al. [9] proved that the main component of CEO may inhibit the adhesion of $S$. mutans to glass, prevent the formation of biofilm, and inhibit developed biofilm. While the formation of biofilm is a complex regulatory process, there are studies available that indicate the effectiveness of CEO as an antibiofilm agent.

The aim of the present study was to analyze the chemical composition and in vitro antimicrobial and antibiofilm activity of CEO. Molecular changes in bacterial biofilms were studied. The effectiveness of the gas phase of CEO against Serratia (S.) marcescens and Penicillium spp. was evaluated using food models.

\section{Results}

\subsection{Chemical Composition of S. aromaticum EO}

The essential oil of $S$. aromaticum was analyzed using gas chromatography with mass spectrometric (GC/MS) and flame ionization (GC-FID) detection. The main components were eugenol $82.4 \%$ and (E)-caryophyllene $14.0 \%$. (Table 1). Based on the chemical composition, the analyzed oil was classified as thymol chemotype.

Table 1. Chemical composition of essential oil from S. aromaticum.

\begin{tabular}{cccc}
\hline No & $\mathbf{R I}^{\mathbf{a}}$ & Compound $^{\mathbf{b}}$ & $\mathbf{\%}^{\mathbf{c}}$ \\
\hline 1 & 830 & furfural & $\mathrm{Tr}$ \\
2 & 983 & 6-methyl-5-hepten-2- & $\mathrm{Tr}$ \\
3 & 1190 & one & $\mathrm{Tr}$ \\
4 & 1193 & methyl salicylate & $\mathrm{Tr}$ \\
5 & 1360 & 2-allyl-phenol & 82.4 \\
6 & 1379 & eugenol & $\mathrm{Tr}$ \\
7 & 1422 & a-copaene & 14.0 \\
8 & 1456 & (E)-caryophyllene & 1.8 \\
9 & 1519 & a-humulene & 0.9 \\
10 & 1583 & eugenol acetate & 0.7 \\
11 & 1755 & caryophyllene oxide & $\mathrm{Tr}$ \\
\hline
\end{tabular}

a Values of retention indices on HP-5MS column; ${ }^{\mathrm{b}}$ identified compounds; ${ }^{\mathrm{c}}$ tr-compounds identified in amounts less than $0.1 \%$. 


\subsection{Antimicrobial Activity of S. aromaticum EO}

The antimicrobial activity of CEO was evaluated by disk diffusion test and the results are presented in Table 2. A weak to moderate inhibitory activity of CEO was observed in the cases of most of the tested bacteria (including biofilm-forming bacteria), and yeast. $S$. aureus was the most susceptible of all the tested bacteria, with CEO showing a very strong inhibitory activity. MIC 50 and MIC 90 were determined by analysis of the minimum inhibitory concentrations. There were low values of MIC $50(85.46 \mu \mathrm{L} / \mathrm{mL})$, and MIC 90 $(93.35 \mu \mathrm{L} / \mathrm{mL})$ values were found for S. aureus. The highest MIC 50 and MIC 90 values were determined for Y. enterocolitica. Moderate MIC 50 and MIC 90 values were determined for B. subtilis and B. subtilis biofilm. Strong antimicrobial activity of CEO against all tested penicillia was observed, with P. expansum being the most susceptible with inhibition zone $18.56 \mathrm{~mm}$ and MIC 5064.25 and MIC $9075.12 \mu \mathrm{L} / \mathrm{mL}$. Details of the results of antimicrobial activity and minimum inhibitory concentrations are given in Table 2.

Table 2. Antimicrobial activity of S. aromaticum essential oil.

\begin{tabular}{|c|c|c|c|c|c|}
\hline Microorganism & Zone Inhibition (mm) & Activity of EO & $\operatorname{MIC~} 50(\mu \mathrm{L} / \mathrm{mL})$ & $\operatorname{MIC} 90(\mu \mathrm{L} / \mathrm{mL})$ & ATB \\
\hline S. enteritidis & $9.44 \pm 1.01$ & * & 216.23 & 265.41 & $29.00 \pm 0.10$ \\
\hline P. aeruginosa & $5.22 \pm 1.20$ & * & 223.38 & 284.56 & $28.00 \pm 0.06$ \\
\hline Y. enterocolitica & $7.67 \pm 1.41$ & * & 224.46 & 278.92 & $28.00 \pm 0.05$ \\
\hline S. marcescens & $10.44 \pm 1.01$ & $* *$ & 112.13 & 145.25 & $27.00 \pm 0.02$ \\
\hline S. aureus & $15.78 \pm 0.67$ & $* * *$ & 85.46 & 93.35 & $29.00 \pm 0.03$ \\
\hline B. subtilis & $11.22 \pm 0.83$ & $* *$ & 121.13 & 138.91 & $26.00 \pm 0.05$ \\
\hline E. faecalis & $4.67 \pm 1.32$ & * & 218.36 & 264.55 & $29.00 \pm 0.03$ \\
\hline C. albicans & $8.22 \pm 1.53$ & * & 221.43 & 226.32 & $28.00 \pm 0.06$ \\
\hline C. krusei & $9.89 \pm 1.76$ & * & 211.82 & 265.33 & $26.00 \pm 0.12$ \\
\hline C. tropicalis & $9.33 \pm 0.58$ & * & 214.54 & 271.36 & $29.00 \pm 0.02$ \\
\hline C. glabrata & $9.33 \pm 1.00$ & * & 217.22 & 264.36 & $26.00 \pm 0.03$ \\
\hline Biofilm S. maltophilia & $8.89 \pm 1.36$ & * & 223.18 & 284.32 & $27.00 \pm 0.05$ \\
\hline Biofilm B. subtilis & $10.44 \pm 0.88$ & ** & 103.64 & 128.64 & $26.00 \pm 0.03$ \\
\hline P. commune & $16.52 \pm 0.15$ & $* * *$ & 74.32 & 81.26 & $25.00 \pm 0.05$ \\
\hline P. expansum & $18.56 \pm 0.22$ & $* * *$ & 64.25 & 75.12 & $26.00 \pm 0.11$ \\
\hline P. glabrum & $18.32 \pm 0.21$ & $* * *$ & 68.41 & 78.12 & $27.00 \pm 0.06$ \\
\hline P. chrysogenum & $17.36 \pm 0.08$ & $* * *$ & 75.11 & 86.92 & $26.00 \pm 0.09$ \\
\hline
\end{tabular}

* Weak antimicrobial activity (zone $5-10 \mathrm{~mm}$ ). ${ }^{* *}$ Moderate inhibitory activity (zone $>10 \mathrm{~mm}$ ). *** Very strong inhibitory activity (zone > $15 \mathrm{~mm}$ ). ATB-antibiotics, positive control (Cefoxitin for $\mathrm{G}^{-}$, Gentamicin for $\mathrm{G}^{+}$, Fluconazole for yeast and fungi).

\subsection{Antimicrobial Analysis In Situ Using a Food Model}

In situ antimicrobial analysis using bread showed that microscopic filamentous fungi of the genus Penicillium were inhibited by CEO vapors in all tested concentrations (Table 3). At the lowest concentration of the oil $(62.5 \mu \mathrm{L} / \mathrm{L})$, P. glabrum was the most strongly inhibited fungus $(42.91 \%)$. The weakest inhibition at this concentration was observed for P. commune. The inhibition of P. expansum was $90.49 \%$ at the concentration of $125 \mu \mathrm{L} / \mathrm{L}$ and $100 \%$ at $250 \mu \mathrm{L} / \mathrm{L}$ and $500 \mu \mathrm{L} / \mathrm{L}$. A significant difference in inhibition was observed for this species between $62.5 \mu \mathrm{L} / \mathrm{L}$ and the remaining concentrations. Significant differences in inhibition of P. glabrum and P. chrysogenum were found between $62.5 \mu \mathrm{L} / \mathrm{L}$ and $250 \mu \mathrm{L} / \mathrm{L}$ or $500 \mu \mathrm{L} / \mathrm{L}$. These findings confirm the inhibitory effects of CEO against the potentially pathogenic fungi tested. 
Table 3. In situ analysis of the antifungal activity of the vapor phase of CEO in bread.

\begin{tabular}{ccccc}
\hline \multicolumn{5}{c}{ Mycelial Growth Inhibition [\%] } \\
\hline \multirow{4}{*}{ Fungi } & \multicolumn{4}{c}{ Concentration of EO } \\
\cline { 2 - 5 } & $\mathbf{6 2 . 5} \boldsymbol{\mu L} / \mathbf{L}$ & $\mathbf{1 2 5} \boldsymbol{\mu L} / \mathbf{L}$ & $\mathbf{2 5 0} \boldsymbol{\mu L / L}$ & $\mathbf{5 0 0} \boldsymbol{\mu L} / \mathbf{L}$ \\
\hline P. commune & $16.41 \pm 6.84^{\mathrm{a}}$ & $45.72 \pm 5.49^{\mathrm{b}}$ & $96.22 \pm 1.20^{\mathrm{c}}$ & $98.78 \pm 1.72^{\mathrm{cd}}$ \\
P. expansum & $16.73 \pm 6.38^{\mathrm{a}}$ & $90.49 \pm 12.26^{\mathrm{b}}$ & $100.00 \pm 0.00^{\mathrm{bc}}$ & $100.00 \pm 0.00^{\mathrm{bd}}$ \\
P. glabrum & $42.91 \pm 5.87^{\mathrm{a}}$ & $54.50 \pm 9.01^{\mathrm{a}}$ & $93.42 \pm 9.30^{\mathrm{b}}$ & $100.00 \pm 0.00^{\mathrm{bc}}$ \\
P. chrysogenum & $30.31 \pm 9.70^{\mathrm{a}}$ & $12.21 \pm 7.87^{\mathrm{a}}$ & $97.90 \pm 1.49^{\mathrm{b}}$ & $99.45 \pm 0.78^{\mathrm{bc}}$ \\
\hline
\end{tabular}

Means \pm standard deviation. Values followed by different superscript within the same row are significantly different $(p<0.05)$.

The effect of the vapor phase of CEO against P. chrysogenum, P. expansum was recorded in in situ analysis using carrots at all tested concentrations, while S. marcescens was only inhibited when the highest concentration of the oil was used (Table 4). The highest inhibition of P. chrysogenum $(93.53 \%)$ and P. expansum $(75.94 \%)$ was observed at the concentration of $500 \mu \mathrm{L} / \mathrm{L}$. The lowest concentration of CEO yielded the lowest inhibition results for both molds. The vapor phase of CEO was shown to have the best inhibitory effect on penicillia in the in situ tests with the food model.

Table 4. Results of in situ analysis of antimicrobial activity of the vapor phase of CEO on carrots.

\begin{tabular}{ccccc}
\hline \multicolumn{4}{c}{ Bacterial Growth Inhibition [\%] } \\
\hline \multirow{4}{*}{ Microorganisms } & \multicolumn{4}{c}{ Concentration of EO } \\
\cline { 2 - 5 } & $\mathbf{6 2 . 5} \boldsymbol{\mu L} / \mathbf{L}$ & $\mathbf{1 2 5} \boldsymbol{\mu L} / \mathbf{L}$ & $\mathbf{2 5 0} \boldsymbol{\mu L / L}$ & $\mathbf{5 0 0} \boldsymbol{\mu L / L}$ \\
\hline P. chrysogenum & $16.93 \pm 0.37^{\mathrm{a}}$ & $51.04 \pm 4.43^{\mathrm{ab}}$ & $61.22 \pm 15.73^{\mathrm{bc}}$ & $93.53 \pm 5.11^{\mathrm{c}}$ \\
P. expansum & $19.43 \pm 0.89^{\mathrm{a}}$ & $59.81 \pm 4.33^{\mathrm{b}}$ & $64.98 \pm 2.81^{\mathrm{b}}$ & $75.94 \pm 0.91^{\mathrm{c}}$ \\
S. marcescens & $0.00 \pm 0.00^{\mathrm{a}}$ & $0.00 \pm 0.00^{\mathrm{a}}$ & $0.00 \pm 0.00^{\mathrm{a}}$ & $49.11 \pm 13.73^{\mathrm{b}}$
\end{tabular}

Means \pm standard deviation. MGI: mycelial growth inhibition, BGI: bacterial growth inhibition; values followed by different superscript within the same row are significantly different $(p<0.05)$.

\subsection{Analysis of Biofilm Developmental Phases and Evaluation of Molecular Differences on Different Surfaces Using MALDI-TOF MS Biotyper}

The effect of CEO on B. subtilis and S. maltophilia biofilms was analyzed using MALDI TOF MS Biotyper in order to observe changes in molecular structure that accompany growth inhibition. The spectra of biofilms and planktonic cells in the control group developed identically and, therefore, the spectra of planktonic cells were used instead of the control spectrum for improved clarity. The two experimental spectra from different surfaces (glass, wood) and the planktonic spectrum representing the development of the control group are shown for each day of the experiment. Figure 1 shows the mass spectra of $B$. subtilis biofilm during individual days of the experimental evaluation.

Mass spectra after days 3 and 5 (Figure 1A,B) of the culture showed the same peaks, indicating production of the same proteins by new biofilms and control planktonic cells. There were no changes observed in bacterial cultures at the protein level. Differences between the mass spectra of biofilms on the tested surfaces (wood, glass) and the control sample stared to emerge on day 7 (Figure 1C-F). This indicated changes in the protein profile of the CEO-treated biofilm. It seems that CEO can influence the homeostasis of a bacterial biofilm formed on wooden and glass surfaces. 

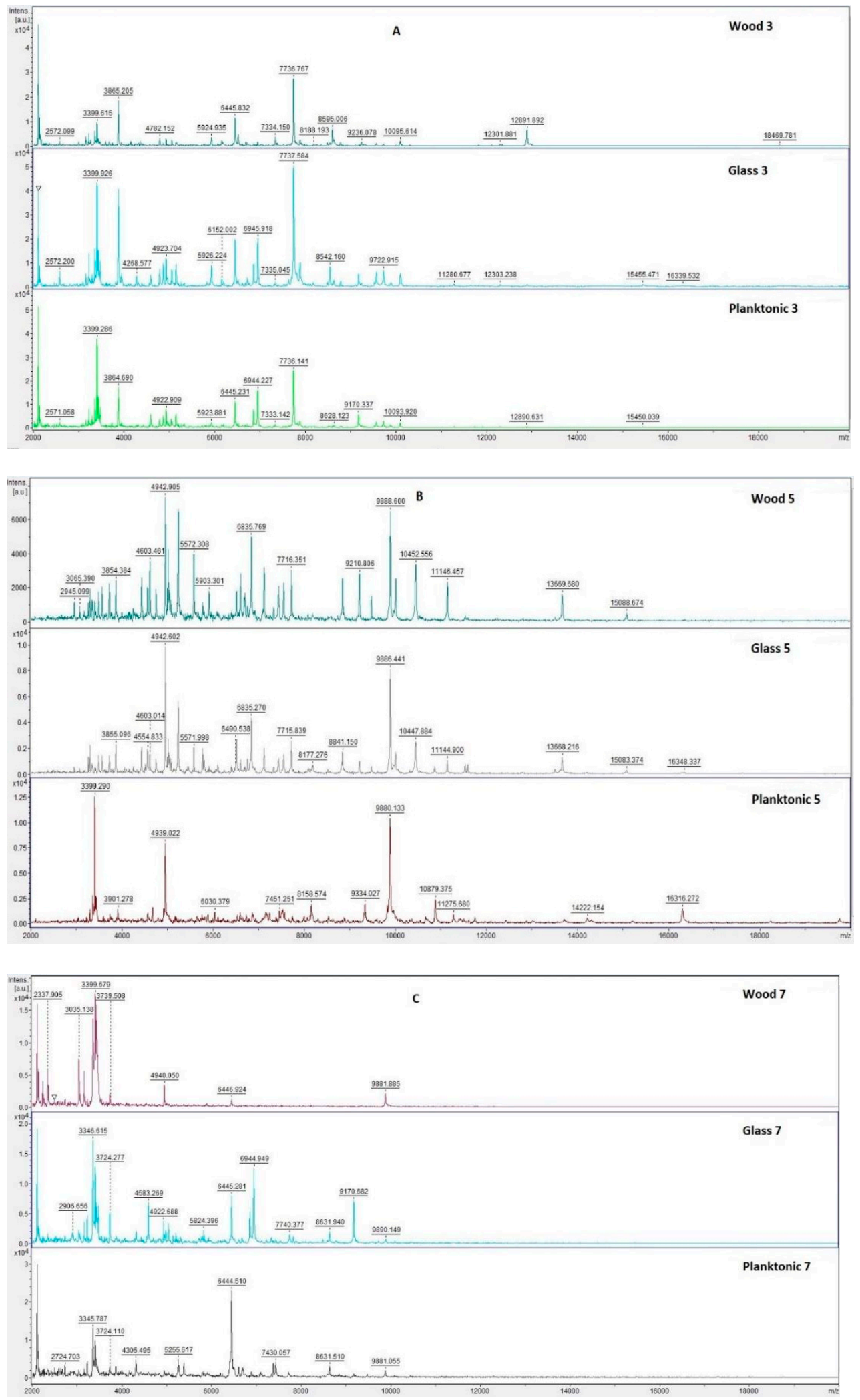

Figure 1. Cont. 

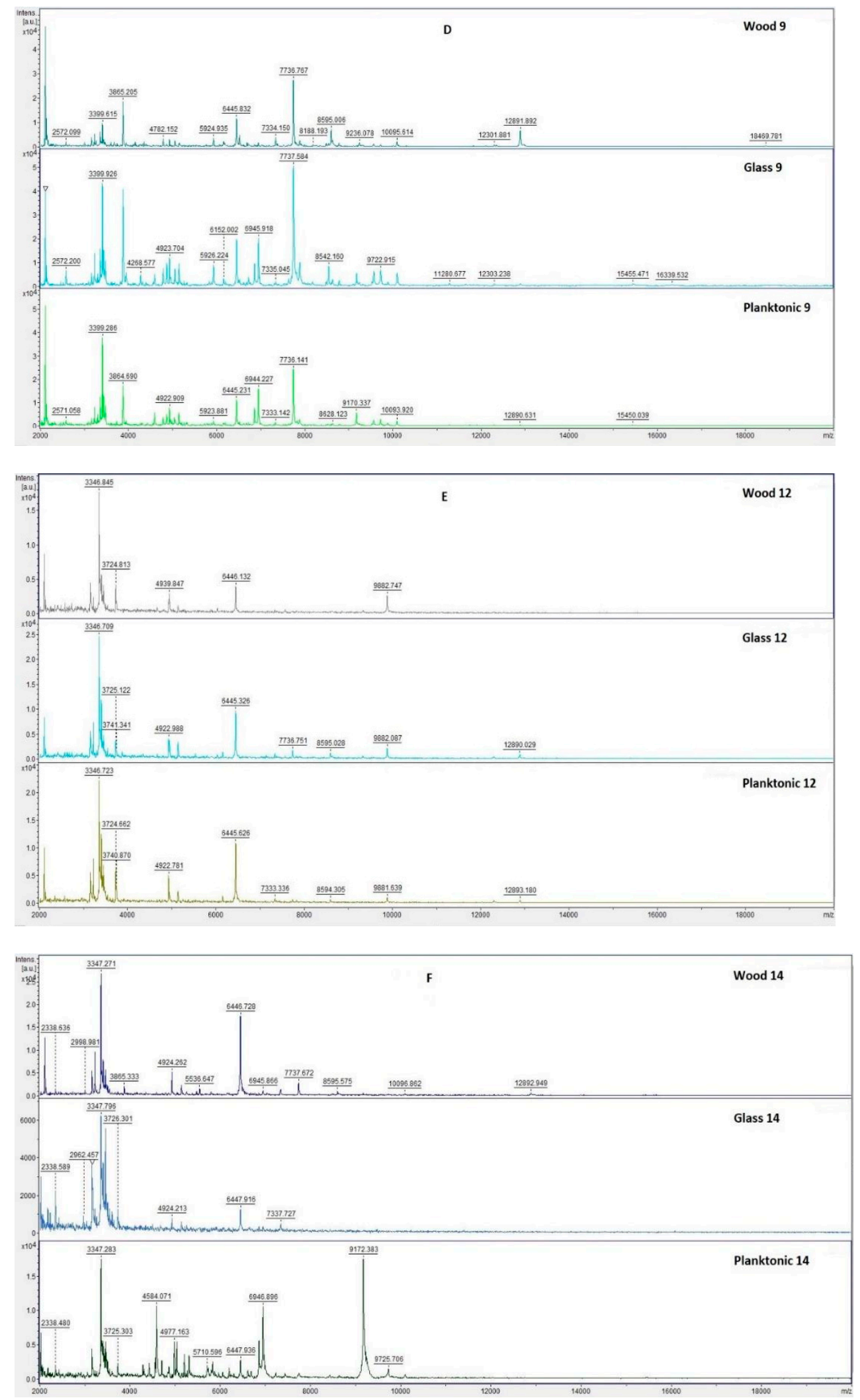

Figure 1. MALDI-TOF mass spectra of B. subtilis biofilm during development after the addition of CEO: (A) 3rd day, (B) 5th day, (C) 7th day, (D) 9th day, (E) 12th day, and (F) 14th day.

Using the data obtained with mass spectrometry, a dendrogram was created to visualize similarities in biofilm structure that are based on MSP distance (Figure 2). It can be stated from the dendrogram that the planktonic stage $(\mathrm{P})$ together with the control groups 
and new biofilms had the shortest distance during the third and fifth days (BSG 3, BSW 3, BSG 5, BSW 5). The similarity in the protein profile of the control groups was confirmed by the short distances of the MSP. New biofilms and control planktonic cells also showed short MSP lengths that corresponded to similar mass spectra. The distance of the experimental groups of SMEs increased gradually over time. The mass spectra analyzed on the 12th and 14th days of the experiment had the longest MSP lengths, indicating changes in the molecular profile of $B$. subtilis.

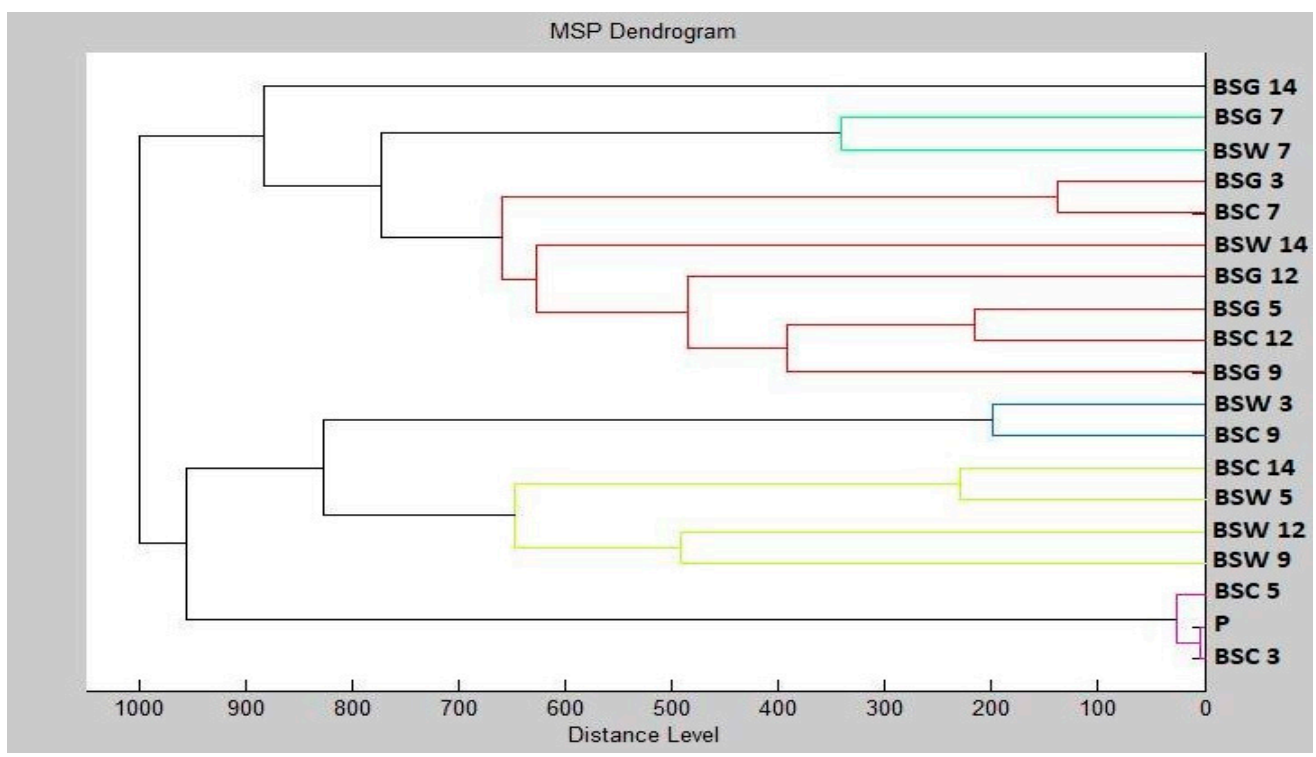

Figure 2. Dendrogram of B. subtilis generated using MSPs of the planktonic cells and the control. BS, B. subtilis; C, control; G, glass; W, wood; and P, planktonic cells.

Figure 3 shows the spectra of developmental stages of S. maltophilia biofilm over the entire duration of the experiment.

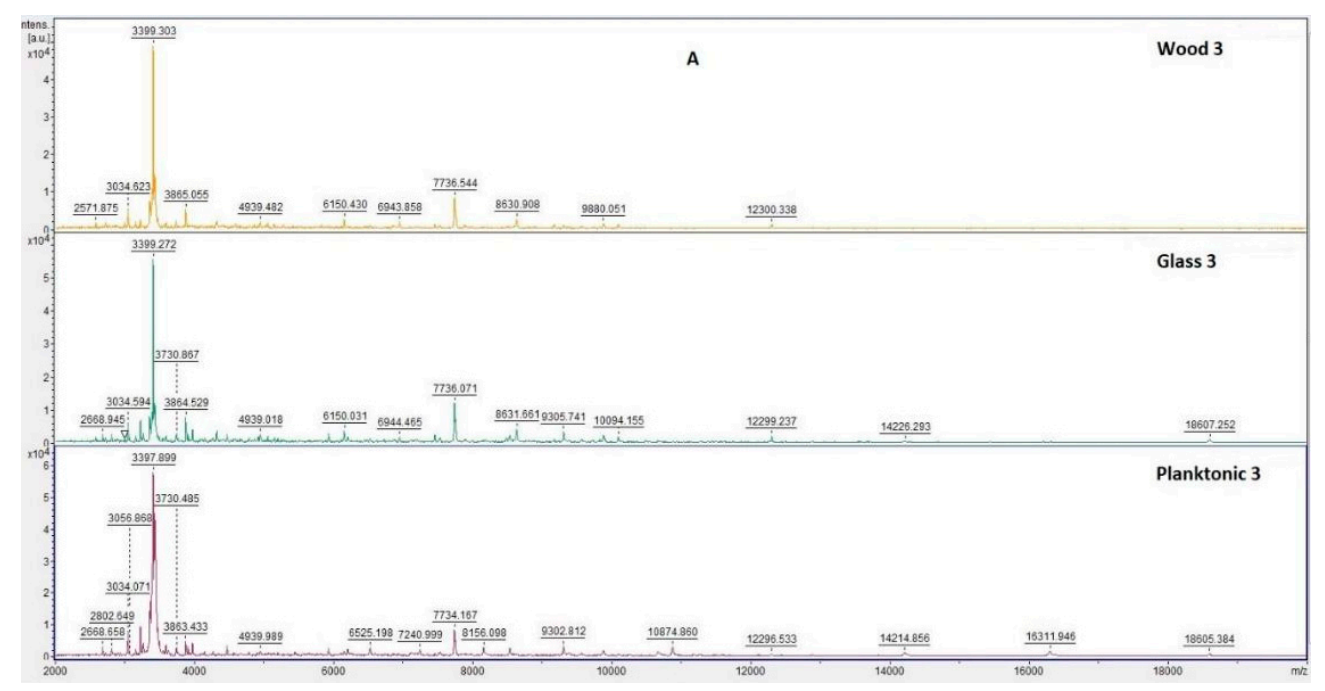

Figure 3. Cont. 

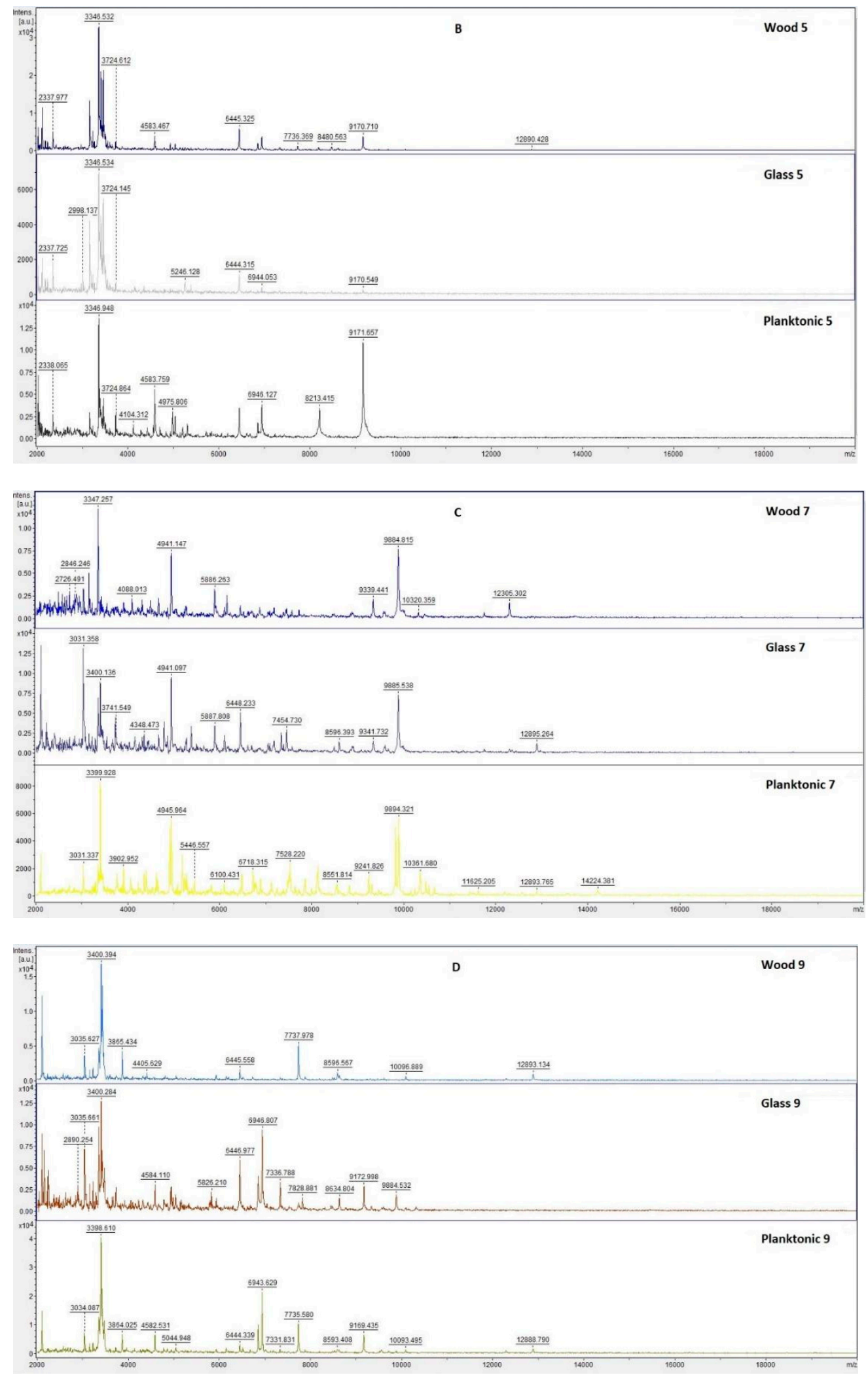

Figure 3. Cont. 

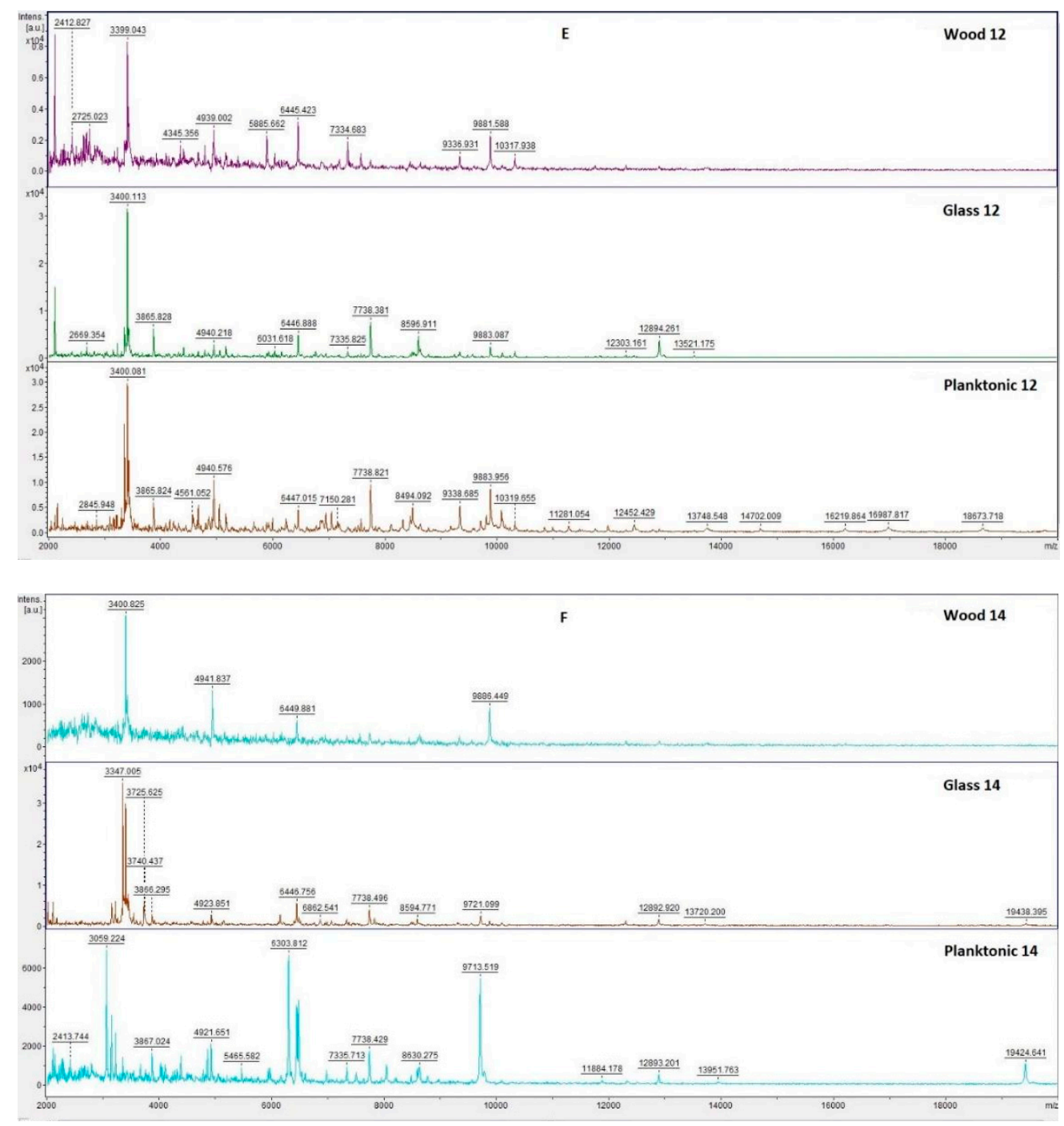

Figure 3. MALDI-TOF mass spectra of S. maltophilia during biofilm development: (A) 3rd day, (B) 5th day, (C) 7th day, (D) 9th day, (E) 12th day, and (F) 14th day.

Analysis of S. maltophilia protein spectra by MALDI-TOF MS Biotyper showed similarity between the experimental spectra and the control planktonic spectrum on the third day of the experiment (Figure 3A), indicating that the bacterial cells in biofilm developed similarly to the planktonic cells. Changes in mass spectra were observed in both experimental groups from the fifth day (Figure 3B-F). This finding confirms the effect of CEO on the protein structure of older biofilms.

Mass spectra dendrogram also confirmed the similarity of the new biofilms to planktonic cells and control cells (Figure 4). The changing distance of MSP during the progression of the experiment indicates differences in protein production due to the effect of the addition of CEO. 


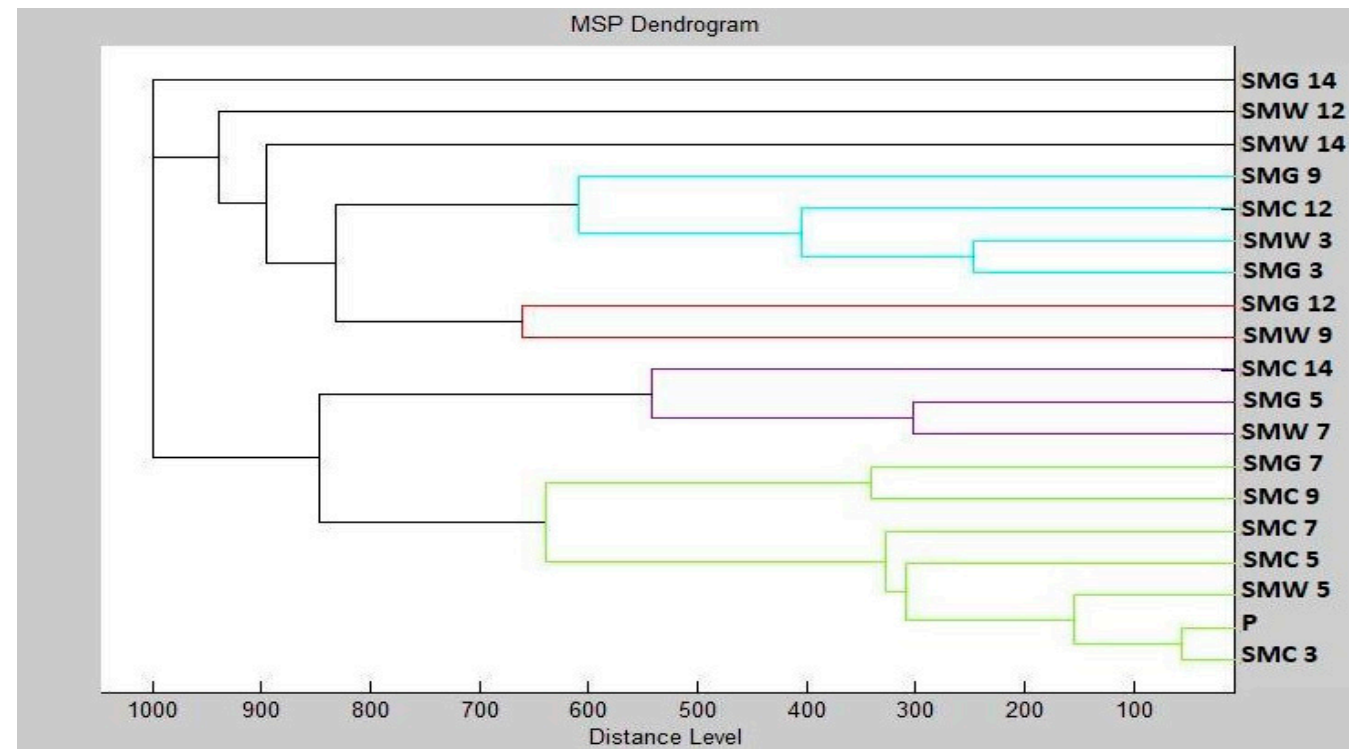

Figure 4. Dendrogram of S. maltophilia generated using MSPs of the planktonic cells and the control. SM, S. maltophilia; C, control; G, glass; W, wood; and P, planktonic cells.

\section{Discussion}

Essential oils are potential sources of novel antimicrobial compounds, especially those active against bacterial pathogens and microscopic filamentous fungi. Chemical composition analysis revealed that the tested essential oil was of the eugenol chemotype. Eugenol was the major compound $(90.3 \%)$, accompanied by $\beta$-caryophyllene $(4.83 \%)$ and eugenol acetate $(1.87 \%)$, in an essential oil extracted from the south of Brazil [10]. In another study where essential oil of clove from the south of Brazil was analyzed, greater quantities of caryophyllene $(39.63 \%)$ and less of eugenol $(56.06 \%)$ were detected [11]. CEO from China [12] and Italy [13] also contained eugenol as their major compound, with $90.84 \%$ and $77.9 \%$, respectively. Similar amounts were found in the present study. The amounts of eugenol and accompanying compounds in the essential oil can be directly related to the different geographic areas of origin of the plant material. They can also be influenced by biotic and abiotic factors such as seasonality, stage of development, age of the plant, and climatic conditions [14]. In addition, the extraction method, such as distillation, which is used for obtaining the oil, can also have an effect on its chemical composition. Moreover, it was found that storage conditions may influence the content of its volatile components [15].

CEO, which is used as an antiseptic in oral infections, inhibits Gram-negative and Gram-positive bacteria as well as microscopic filamentous fungi. There are many reports that prove that clove oil and its main active component, eugenol, affect common, foodderived, Gram-negative bacteria such as Escherichia coli, Salmonella, P. aeruginosa, etc., and Gram-positive bacteria such as Staphylococcus, Streptococcus, Listeria, etc. This conclusion is based on the reported inhibiting effects on migration, adhesion, expression of virulence factors, and biofilm formation in these bacteria. Clove oil and eugenol have good prospects for application in the food antisepsis field [16]. With the disk diffusion method, we found the antimicrobial activity against the tested microorganisms, including biofilm-forming bacteria, to be either weak or very strong. S. aureus was found to be the most susceptible to $\mathrm{CEO}$ among the bacteria tested. In another study, $\mathrm{CEO}$ was active against standard strains of Gram-negative and Gram-positive bacteria, showing inhibition zones between 14 and $25 \mathrm{~mm}$ in the disk diffusion test [17]. The authors reported intermediate bacterial activity of the oil against food bacteria with inhibition diameters of $14.6 \pm 1.7 \mathrm{~mm}$ for P. putida, $15 \pm 0.66 \mathrm{~mm}$ for $E$. coli, and $15.6 \pm 0.4 \mathrm{~mm}$ for S. aureus. In a different research, inhibition zones ranging from $21.3 \pm 2.2 \mathrm{~mm}$ for $S$. aureus ATCC and $35.6 \pm 2.7 \mathrm{~mm}$ for P. aeruginosa ATCC were observed [18]. The results of our study differed from the ones referenced where the zones of inhibition were generally smaller. Cimanga et al. [19] reported that CEO 
could be a strong inhibitor of $S$. aureus and E. coli and a moderate inhibitor of P. aeruginosa. Using the microdilution method, Gislene et al. [20], Hili et al. [21], and Nzeako et al. [22] found that CEO manifested antimicrobial activity against $S$. aureus, E. coli, and C. albicans at various concentrations of the extracts. The sensitivity to the antimicrobial effect of CEO (in descending order) was E. coli with MIC $2 \mu \mathrm{L} / \mathrm{mL}$, C. albicans with MIC $16 \mu \mathrm{L} / \mathrm{mL}$, E. faecalis with MIC $32 \mu \mathrm{L} / \mathrm{mL}$, and S. aureus with MIC $32 \mu \mathrm{L} / \mathrm{mL}$ [23]. Different results were found using microdilution methods in our study. Clove oil has a strong antimicrobial activity. Its minimum inhibitory concentration in the range of $0.2-0.625 \mathrm{mg} / \mathrm{mL}$ was recorded against the bacteria S. aureus, Staphylococcus epidermidis, E. coli, and P. aeruginosa [24-26].

From among the microscopic fungi tested in our study, P. expansum was found to be the most susceptible to CEO. Among the tested yeasts, C. krusei was the least resistant. Eugenol from the clove is the essential ingredient that is responsible for its antifungal activity [27]. A strong antifungal activity of CEO was reported against opportunistic fungal pathogens such as C. albicans, Cryptococcus neoformans, and Aspergillus fumigatus. A considerable variation in inhibition zone sizes, ranging from 12 to $22 \mathrm{~mm}$, was observed among fungal isolates depending on their sensitivity to CEO [28]. Nunez et al. [29] reported a strong fungicidal effect of eugenol against C. albicans, P. citrinum, A. niger, and T. mentagrophytes. Ahmad et al. [30] also reported strong antifungal activity of clove oil against C. albicans, $C$. neoformans, and A. fumigatus. Pinto et al. [31] determined MIC to evaluate the antifungal activity of the clove oil and its main component, eugenol, against Candida, Aspergillus, and clinical and ATCC strains of dermatophytes. Similar to our results, the essential oil and eugenol showed inhibitory activity against all the tested strains. Chami et al. [32] confirmed carvacrol and eugenol as strong potential antifungal agents and suggested their use as therapeutic agents for oral candidiasis.

The effect of the vapor phase of CEO against $P$. chrysogenum and P. expansum was recorded at all tested concentrations in in situ analysis using carrots. Noteworthy, $S$. marcescens was inhibited only when the oil was applied in the concentration of $500 \mu \mathrm{L} / \mathrm{L}$. The investigation of inhibition of the microscopic filamentous by vapor phase CEO also indicated the susceptibility of penicillia. In the bread model studies, the best inhibition result was observed against $P$. expansum at concentrations of 250 and $500 \mu \mathrm{L} / \mathrm{mL}$. In the carrot model studies, $P$. chrysogenum was found to be the most susceptible. There exists a different study in which the antifungal activities of CEO and its volatile vapor against dermatophytic fungi, including C. albicans, Epidermophyton floccosum. Microsporum audouinii, Trichophyton mentagrophytes, and Trichophyton rubrum, were studied. Spore germination and mycelial growth were found to be strongly inhibited by both the oil and its volatile vapor. Moreover, the volatile vapor of $\mathrm{CEO}$ showed fungistatic activity, whereas the direct application of the oil resulted in a fungicidal effect [33]. Jain and Agrawal [34] noticed fungistatic activity of volatile vapor of several essential oils. No other authors focused on antifungal activity of volatile vapor of clove oil. There are studies in which the differences in inhibitory activity of essential oils in different food model systems were investigated [35]. It was found that CEO did not have a significant effect on the count of E. coli O157: H7 relative to control; however, it showed significant inhibitory effect in blanched spinach at similar concentration [36]. Aguilar-Gonzalez et al. [37] evaluated the antifungal activity of the vapor phase of clove and mustard EOs, individually and in combination, against gray mold (Botrytis cinerea) in strawberries, and noted inhibitory activity.

Bacterial biofilms can be characterized as non-homogenous structures with a high surface roughness, diversification of cells' metabolic activity, and presence of extracellular polymeric substances as well as cells' and spores' liberation from the upper parts of the biofilm matrix [38]. The difference between the mass spectra of B. subtilis biofilms on the tested surfaces (wood, glass) and the control sample was noticeable from the seventh day in our study. There were some changes in mass spectra of S. maltophilia in both experimental groups from the fifth day. These results confirmed the effect of CEO on the protein structure of older biofilms. CEO is one of the most bioactive essential oils due to high antimicrobial activity of eugenol [39]. The main compound of the oil used in 
the presented research was eugenol, which constituted $86.99 \%$ of it. As demonstrated in another study, the activity of CEO against Alicyclobacillus biofilm may be related to both its bactericidal effect, resulting in a decrease in the number of planktonic cells, and the changes in the adherence capability of cells [40]. MALDI-TOF MS Biotyper has only been used in a few cases. Li et al. [41] analyzed B. subtilis biofilm and determined the spatial distribution of specific peptides and lipopeptides that are produced in biofilms by using this method. Kubesová et al. [42] used MALDI-TOF MS to analyze the biofilm produced by the genus Candida. Rams et al. [43] found out that the phenotypic identification of culturable $P$. gingivalis biofilms is $100 \%$ accurate using MALDI-TOF MS because of the differences in the protein profile. The changes in the mass spectra profile were demonstrated by MALDI-TOF in Kačániová et al. [44,45], where inhibitory effects on the biofilm of Coriandrum sativum and Citrus aurantium EOs were detected. The use of MALDI-TOF can be a fast and easy method for the assessment of the biofilm growth and degradation due to structural and molecular changes.

\section{Materials and Methods}

\subsection{Essential Oil}

The essential oil of S. aromaticum was obtained from Hanus, s.r.o. (Nitra, Slovakia). It was a product of steam distillation of fresh leaves from 2021. It was stored in the dark at $4{ }^{\circ} \mathrm{C}$ for the whole time. The analyses were carried out in 2021.

\subsection{Chemical Characterization of Essential Oil Samples by Gas Chromatography/Mass Spectrometry (GC/MS) and Gas Chromatography (GC-FID)}

GC/MS analysis of CEO was performed using an Agilent $6890 \mathrm{~N}$ gas chromatograph (Agilent Technologies, Santa Clara, CA, USA) coupled to a quadrupole mass spectrometer 5975B (Agilent Technologies, Santa Clara, CA, USA) equipped with an HP-5MS capillary column $(30 \mathrm{~m} \times 0.25 \mathrm{~mm} \times 0.25 \mu \mathrm{m})$. The temperature ramp was from $60^{\circ} \mathrm{C}$ to $150{ }^{\circ} \mathrm{C}$ (increasing rate $3{ }^{\circ} \mathrm{C} / \mathrm{min}$ ) and from $150{ }^{\circ} \mathrm{C}$ to $280^{\circ} \mathrm{C}$ (increasing rate $5^{\circ} \mathrm{C} / \mathrm{min}$ ). The total run time of the program was $60 \mathrm{~min}$. Helium 5.0 was used as the carrier gas with a flow rate of $1 \mathrm{~mL} / \mathrm{min}$. The injection volume was $1 \mu \mathrm{L}$ (EO sample was diluted in pentane), while the split/splitless injector temperature was set at $280^{\circ} \mathrm{C}$. Split mode injection with split ratio at 40.8:1 was used. The electron-impact mass spectrometric data (EI-MS; $70 \mathrm{eV}$ ) were acquired in scan mode over the $\mathrm{m} / \mathrm{z}$ range $35-550$. MS ion source and MS quadrupole temperatures were $230^{\circ} \mathrm{C}$ and $150{ }^{\circ} \mathrm{C}$, respectively. Acquisition of data started after $3 \mathrm{~min}$ of solvent delay time.

GC-FID analyses were performed on Agilent 6890N gas chromatograph coupled to FID detector. Column (HP-5MS) and chromatographic conditions were the same as for GC-MS. The temperature of the FID detector was set at $300^{\circ} \mathrm{C}$.

The individual volatile constituents of $S$. aromaticum EO sample were identified according to their retention indices [46] and they were compared with the reference spectra (Wiley and NIST databases). The retention indices were determined experimentally by standard method, which included retention times of n-alkanes (C6-C34), injected under the same chromatographic conditions [47]. The percentages of the identified compounds (amounts higher than $0.1 \%$ ) were derived from their GC peak areas.

\subsection{Tested Microorganisms}

Gram-positive bacteria (B. subtilis CCM 1999, E. faecalis CCM 4224, S. aureus subsp. aureus CCM 8223), gram-negative bacteria (P. aeruginosa CCM 3955, S. enterica subsp. enterica ser. Enteritidis CCM 4420, S. marcescens CCM 8588 Y. enterocolitica CCM 7204), and yeasts (C. krusei CCM 8271, C. albicans CCM 8261, C. tropicalis CCM 8223, C. glabrata CCM 8270) were obtained from the Czech collection of microorganisms (Brno, Czech Republic). The biofilm-forming bacteria B. subtilis and S. maltophilia were obtained from the dairy industry. Bacteria were identified with $16 \mathrm{~S}$ rRNA sequencing and MALDI-TOF MS Biotyper. The 
fungi P. glabrum, P. chrysogenum, P. expansum, and P. commune were obtained from grape samples, and were identified by $16 \mathrm{~S}$ rRNA sequencing and MALDI-TOF MS Biotyper.

\subsection{Antimicrobial Activity: Disc Diffusion Method}

Antimicrobial activity of $S$. aromaticum $\mathrm{EO}$ was determined by the disc diffusion method. The microbial inoculum was cultivated for $24 \mathrm{~h}$ on Tryptone soya agar (TSA, Oxoid, Basingstoke, UK) at $37^{\circ} \mathrm{C}$ for bacteria and Sabouraud Dextrose Agar (SDA, Oxoid, Basingstoke, UK) at $25^{\circ} \mathrm{C}$ for yeasts. The inoculum was adjusted to optical density $0.5 \mathrm{McF}$ arland standard $\left(1.5 \times 10^{8} \mathrm{CFU} / \mathrm{mL}\right)$ and $100 \mu \mathrm{L}$ was added on plates with Mueller Hinton agar (MHA, Oxoid, Basingstoke, UK). Sterile 6-mm discs saturated with $10 \mu \mathrm{L}$ of $S$. aromaticum $\mathrm{EO}$ were placed on the layer of agar containing the suspension of microorganisms. The samples were incubated for $24 \mathrm{~h}$ at $37^{\circ} \mathrm{C}$ for bacteria and $25^{\circ} \mathrm{C}$ for yeasts. Two antibiotics (Cefoxitin, Gentamicin, Oxoid, Basingstoke, UK), and one antifungal (Fluconazole, Oxoid, Basingstoke, UK) were used as positive controls for gram-negative and gram-positive bacteria and yeasts, respectively. Disks impregnated with $0.1 \%$ DMSO (dimethylsulfoxid, Centralchem, Bratislava, Slovakia) served as negative control. The antimicrobial activity was categorized as either very strong, moderate, or weak when the zone of growth inhibition was larger than 15,10 , and $5 \mathrm{~mm}$, respectively. The analyses were performed in triplicate.

\subsection{Minimum Inhibitory Concentrations (MIC)}

Microbial inoculum was cultivated for $24 \mathrm{~h}$ in Mueller Hinton Broth (MHB, Oxoid, Basingstoke, UK) at $37^{\circ} \mathrm{C}$ for bacteria and Sabouraud Dextrose Broth (SDB, Oxoid, Basingstoke, UK) at $25^{\circ} \mathrm{C}$ for yeasts. An aliquot of $50 \mu \mathrm{L}$ of inoculum with an optical density of $0.5 \mathrm{McF}$ arland was added to a 96-well microtiter plate. Subsequently, the S. aromaticum EO was prepared by serial dilution to a concentration range from $400 \mu \mathrm{L} / \mathrm{mL}$ to $0.2 \mu \mathrm{L} / \mathrm{mL}$ in $\mathrm{MHB} / \mathrm{SDB}$, and $100 \mu \mathrm{L}$ of suspension was thoroughly mixed with bacterial inoculum in wells. Bacterial samples were incubated for $24 \mathrm{~h}$ at $37^{\circ} \mathrm{C}$. Yeast samples were incubated for $24 \mathrm{~h}$ at $25^{\circ} \mathrm{C}$. MHB/SDB with EO was used as a negative control and MHB/SDB with inoculum was used as positive control, representing uninhibited growth.

For non-adherent microorganisms, the absorbance was measured after an incubation period at $570 \mathrm{~nm}$ by Glomax spectrophotometer (Promega Inc., Madison, WI, USA). The MIC of biofilm-forming bacteria was measured with the use of crystal violet. The suspension with non-attached cells was discarded, the wells were washed with distilled water three times, and left to dry at room temperature. Following the addition of $200 \mu \mathrm{L}$ of $0.1 \%$ $(w / v)$ crystal violet to the wells, the plates were incubated for $15 \mathrm{~min}$. Subsequently, the wells were repeatedly washed and dried. Stained biofilms were solubilized with $200 \mu \mathrm{L}$ of $33 \%$ acetic acid [48], and absorbance was measured at $570 \mathrm{~nm}$. Minimum inhibitory concentration was determined as the concentration of CEO at which absorbance was lower than the absorbance of the maximal growth control. The test was performed in triplicate.

\subsection{Antimicrobial Analysis In Situ on a Food Model}

Antifungal effect of $S$. aromaticum $\mathrm{EO}$ vapor phase was evaluated in 0.5-L sterile, glass jars (Bormioli Rocco, Fidenza, Italy) on a bread surface used as a food model. The fungi of Penicillium genus were cultivated for 5 days on Sabouraud Dextrose agar (SDA, Oxoid, Basingstoke, UK) at the temperature $25^{\circ} \mathrm{C}$. The cultures were applied to the bread slices $(15 \times 15 \times 1.5 \mathrm{~cm})$ by three stabs. A 6 -cm sterile, filter paper was placed to the jar lid and $100 \mu \mathrm{L}$ of CEO $(62.5,125,250$, and $500 \mu \mathrm{L} / \mathrm{L}$ diluted in ethyl acetate) were applied. The control group was left untreated. The jars were hermetically sealed and they were incubated in the dark for 14 days at $25^{\circ} \mathrm{C} \pm 1{ }^{\circ} \mathrm{C}$.

Antibacterial analysis of the vapor phase of CEO in situ was tested on S. marcescens. Warm MHA was poured into 60-mm Petri dishes (PD) and in the lid too. Sliced carrots $(0.5 \mathrm{~mm})$ were placed on agar. Then, an inoculum was prepared, as previously described. CEO was diluted in ethyl acetate to $500,250,125$, and $62.5 \mu \mathrm{L} / \mathrm{L}$ and applied to sterile filter 
paper. After evaporation of the remaining ethyl acetate $(1 \mathrm{~min})$, the dishes were sealed and incubated at $37^{\circ} \mathrm{C}$ for 7 days.

Inhibition of the fungal growth was evaluated by stereological methods. Volume density $(\mathrm{Vv})$ of fungi was estimated using ImageJ software. The stereological grid points of the colonies $(\mathrm{P})$ and substrate $(\mathrm{p})$ were counted. The density of fungal growth was calculated as percentage (\%) according to the formula $\mathrm{Vv}=\mathrm{P} / \mathrm{p} \times 100$. The antifungal activity of EO was expressed as mycelial growth inhibition in percentage (\%) (MGI): MGI $=[(C-T) / C] \times 100$, where $C$ was density of the fungal growth in the control group and $\mathrm{T}$ was density of the fungal growth in the treatment group $[49,50]$.

In situ bacterial growth was determined using stereological methods. In this concept, the volume density $(\mathrm{Vv})$ of bacterial colonies was first estimated using ImageJ software counting the points of the stereological grid hitting the colonies (P) and those (p) falling to the reference space (growth substrate used). The volume density of bacterial colonies was consequently calculated as follows: $\mathrm{Vv}(\%)=\mathrm{P} / \mathrm{p}$. The antibacterial activity of $\mathrm{EO}$ was defined as the percentage of bacterial growth inhibition $(B G I) B G I=[(C-T) / C] \times 100$, where $\mathrm{C}$ and $\mathrm{T}$ were bacterial growth (expressed as $\mathrm{Vv}$ ) in the control group and the treatment group, respectively. Negative results represented growth stimulation.

\subsection{Analysis of Differences in Biofilm Development with MALDI-TOF MS Biotyper}

The changes of protein spectra during biofilm development after CEO addition were evaluated by MALDI-TOF MS Biotyper. S. maltophilia was used as a representative of gram-negative biofilm-forming bacteria and B. subtilis was representative of gram-positive biofilm-forming bacteria, and both bacterial strains were isolated from the milk industry. The biofilm-forming bacteria were added to $50-\mathrm{mL}$ polypropylene tubes with $20 \mathrm{~mL}$ of MHB; subsequently, a wooden toothpick and a glass slide were added as models of different surfaces. The experimental groups were treated with $0.1 \% \mathrm{CEO}$, and control group samples were left untreated. The samples were incubated at $37^{\circ} \mathrm{C}$ on a shaker at $170 \mathrm{rpm}$. The samples were analyzed after $3,5,7,9,12$, and 14 days. The biofilm samples were taken from a glass slide and wooden toothpick with a sterile cotton swab, and they were imprinted onto a MALDI TOF metal target plate. The planktonic cells were obtained from $300 \mu \mathrm{L}$ of culture medium, cells were centrifuged for $1 \mathrm{~min}$ at 12,000 rpm, and the supernatant was discarded. The pellet was resuspended in $30 \mu \mathrm{L}$ of ultrapure water and the suspension was centrifuged for $1 \mathrm{~min}$ at 12,000 rpm. This cycle was repeated three times. Then $1 \mu \mathrm{L}$ of the so-prepared planktonic cell suspension was applied to a target plate. The target plate was dried and $1 \mu \mathrm{L}$ of $\alpha$-Cyano-4-hydroxycinnamic acid matrix $(10 \mathrm{mg} / \mathrm{mL})$ was applied. The samples were processed with MALDI-TOF MicroFlex (Bruker Daltonics) linear and positive mode for the range of $\mathrm{m} / \mathrm{z}$ 200-2000 after crystallization. The spectra were obtained by an automatic analysis and the same sample similarities were used to generate the standard global spectrum (MSP) and the 19 MSP was generated from the spectra by MALDI Biotyper 3.0 and were grouped into dendrograms using Euclidean distance [44].

\subsection{Statistical Data Evaluation}

$\mathrm{SAS}^{\circledR}$ software version 8 was used for data processing. The results of the MIC value (concentration that caused $50 \%$ and $90 \%$ inhibition in bacterial growth) were determined by logit analysis.

\section{Conclusions}

The main components of the essential oil of S. aromaticum were eugenol $82.4 \%$ and (E)-caryophyllene $14.0 \%$. A very strong antifungal effect of the vapor phase of the essential oil against the genus $P$. expansum was observed in the experiments that employed the food model (bread). Strong inhibiting effects of the vapor phase against $P$. chrysogenum were also noted in the test with carrots. The results indicate that CEO has potential for future use in extension of the shelf life of bakery products and that it could find application in the storage of root vegetables. The tested oil had moderate antimicrobial as well as 
antibiofilm effects that were observed on various surfaces and detected by MALDI-TOF MS Biotyper. In the case of EOs with a dominant proportion of volatile components, a stronger effect was often observed in the vapor phase in comparison to direct contact application. The decrease in microbial population caused by the addition of CEO depended on the concentration, and the inhibitory activity of the oil was lower in food systems when compared to in vitro systems.

Author Contributions: Conceptualization, L.G. and M.K.; Data curation, L.G., P.B., V.V., H.D.., N.L.V., M.V. and M.K.; Methodology, L.G., P.B., N.L.V., M.V., H.Ď., V.V. and M.K.; Supervision, M.K.; Writing—original draft, L.G., P.B., P.Ł.K., H.A.H.S.-A.A., W.M.H., T.S., D.G. and M.K. All authors have read and agreed to the published version of the manuscript.

Funding: This work was supported by the grant APVV SK-BY-RD-19-0014 "The formulation of novel compositions and properties study of the polysaccharides based edible films and coatings with antimicrobial and antioxidant plant additives".

Institutional Review Board Statement: Not applicable.

Informed Consent Statement: Not applicable.

Data Availability Statement: Data are contained within the article.

Acknowledgments: This work was supported by the grants of the VEGA no. 1/0180/20.

Conflicts of Interest: The authors declare no conflict of interest.

\section{References}

1. Singh, J.; Baghotia, A.; Goel, S.P. Eugenia caryophyllata Thunberg (Family Myrtaceae): A review. Int. J. Res. Pharm. Biomed. Sci. 2012, 3, 1469-1475.

2. Lee, S.; Najiah, M.; Wendy, W.; Nadirah, M. Chemical composition and antimicrobial activity of the essential oil of Syzygium aromaticum flower bud (Clove) against fish systemic bacteria isolated from aquaculture sites. Front. Agric. China 2009, 3, 332-336. [CrossRef]

3. Chaieb, K.; Zmantar, T.; Ksouri, R.; Hajlaoui, H.; Mahdouani, K.; Abdelly, C.; Bakhrouf, A. Antioxidant properties of the essential oil of Eugenia caryophyllata and its antifungal activity against a large number of clinical Candida species. Mycoses 2007, 50, 403-406. [CrossRef]

4. Shobana, S.; Naidu, K.A. Antioxidant activity of selected Indian spices. Prostaglandins Leukot. Essent. Fat. Acids (PLEFA) 2000, 62, 107-110. [CrossRef] [PubMed]

5. Burt, S. Essential oils: Their antibacterial properties and potential applications in foods-A review. Int. J. Food Microbiol. 2004, 94, 223-253. [CrossRef] [PubMed]

6. Soliman, K.M.; Badeaa, R.I. Effect of oil extracted from some medicinal plants on different mycotoxigenic fungi. Food Chem. Toxicol. 2002, 40, 1669-1675. [CrossRef]

7. Budri, P.E.; Silva, N.C.C.; Bonsaglia, E.C.R.; Júnior, A.F.; Júnior, J.P.A.; Doyama, J.T.; Gonçalves, J.L.; Santos, M.V. Effect of essential oils of Syzygium aromaticum and Cinnamomum zeylanicum and their major components on biofilm production in Staphylococcus aureus strains isolated from milk of cows with mastitis. J. Dairy Sci. 2015, 98, 5899-5904. [CrossRef] [PubMed]

8. Rajkowska, K.; Nowicka-Krawczyk, P.; Kunicka-Styczyńska, A. Effect of clove and thyme essential oils on Candida biofilm formation and the oil distribution in yeast cells. Molecules 2019, 24, 1954. [CrossRef]

9. Adil, M.; Singh, K.; Verma, P.K.; Khan, A.U. Eugenol-induced suppression of biofilm-forming genes in Streptococcus mutans: An approach to inhibit biofilms. J. Glob. Antimicrob. Resist. 2014, 2, 286-292. [CrossRef] [PubMed]

10. Silvestri, J.D.F.; Paroul, N.; Czyewski, E.; Lerin, L.; Rotava, I.; Cansian, R.L.; Mossi, A.; Toniazzo, G.; de Oliveira, D.; Treichel, H. Chemical composition and antioxidant and antibacterial activities of clove essential oil (Eugenia caryophyllata Thunb). Rev. Ceres 2018, 57, 589-594. [CrossRef]

11. Radünz, M.; da Trindade, M.L.M.; Camargo, T.M.; Radünz, A.L.; Dellinghausen Borges, C.; Gandra, E.A.; Helbig, E. Antimicrobial and antioxidant activity of unencapsulated and encapsulated clove (Syzygium aromaticum, L.) essential oil. Food Chem. 2019, 276, 180-186. [CrossRef]

12. Zhang, Y.; Wang, Y.; Zhu, X.; Cao, P.; Wei, S.; Lu, Y. Antibacterial and antibiofilm activities of eugenol from essential oil of Syzygium aromaticum (L.) merr. \& L. M. Perry (clove) leaf against periodontal pathogen Porphyromonas gingivalis. Microb. Pathog. 2017, 113, 396-402. [CrossRef] [PubMed]

13. Ebani, V.V.; Najar, B.; Bertelloni, F.; Pistelli, L.; Mancianti, F.; Nardoni, S. Chemical composition and in vitro antimicrobial efficacy of sixteen essential oils against Escherichia coli and Aspergillus fumigatus isolated from poultry. J. Vet. Sci. 2018, 5, 62. [CrossRef] [PubMed] 
14. Andrade, B.F.M.T.; Nunes Barbosa, L.; Probst, I.P.; Fernandes Júnior, A. Antimicrobial activity of essential oils. J. Essent. Oil Res. 2017, 26, 34-40. [CrossRef]

15. Besten, M.A.; Jasinski, V.C.; Costa, Â.D.G.; Nunes, D.S.; Sens, S.L.; Wisniewski, A., Jr.; Simionatto, E.L.; Riva, D.; Dalmarco, J.B.; Granato, D. Chemical composition similarity between the essential oils isolated from male and female specimens of each five Baccharis species. J. Braz. Chem. Soc. 2020, 23, 1041-1047. [CrossRef]

16. Hu, Q.; Zhou, M.; Wei, S. Progress on the Antimicrobial Activity Research of Clove Oil and Eugenol in the Food Antisepsis Field. J. Food Sci. 2018, 83, 1476-1483. [CrossRef]

17. Teles, A.M.; Silva-Silva, J.V.; Fernandes, J.M.P.; Abreu-Silva, A.L.; Calabrese, K.D.S.; Mendes Filho, N.E.; Mouchrek, A.N.; Almeida-Souza, F. GC-MS Characterization of Antibacterial, Antioxidant, and Antitrypanosomal Activity of Syzygium aromaticum Essential Oil and Eugenol. Evid. Based Complement Alternat. Med. 2021, 2021, 6663255. [CrossRef]

18. Lalami, A.E.; Moukhafi, K.; Bouslamti, R.; Lairini, S. Evaluation of antibacterial and antioxidant effects of cinnamon and clove essential oils from Madagascar. Mater. Today Proc. 2019, 13, 762-770. [CrossRef]

19. Cimanga, K.; Kambu, K.; Tona, L.; Apers, S.; De Bruyne, T.; Hermans, N.; Totté, J.; Pieters, L.; Vlietinck, A.J. Correlation between chemical composition and antibacterial activity of essential oils of some aromatic medicinal plants growing in the democratic republic of Congo. J. Ethnopharmacol. 2020, 79, 213-220. [CrossRef]

20. Gislene, G.F.; Paulo, C.; Giuliana, L. Antibacterial activity of plant extracts and phytochemicals on antibiotic resistant bacteria. Braz. J. Microbiol. 2000, 31, 314-325. [CrossRef]

21. Hili, P.; Evans, C.S.; Veness, R.G. Antimicrobial action of essential oils: The effect of dimethylsulphoxide on the activity of cinnamon oil. Lett. Appl. Microbiol. 1997, 24, 269-275. [CrossRef] [PubMed]

22. Nzeako, B.C.; Al-Kharousi, Z.S.; Al-Mahrooqui, Z. Antimicrobial activities of clove and thyme extracts. Sultan Qaboos Univ. Med. J. 2006, 6, 33-39. [PubMed]

23. Thosar, N.; Basak, S.; Bahadure, R.N.; Rajurkar, M. Antimicrobial efficacy of five essential oils against oral pathogens: An in vitro study. Eur. J. Dent. 2013, 07, S071-S077. [CrossRef]

24. Fu, Y.; Zu, Y.; Chen, L.; Shi, X.; Wang, Z.; Sun, Z.; Effert, T. Antimicrobial activity of clove and rosemary essential oils alone and in combination. Phytother. Res. 2007, 21, 989-994. [CrossRef]

25. Nuñez, L.; D'Aquino, M. Microbicide activity of clove essential oil (Eugenia caryophyllata). Braz. J. Microbiol. 2012, 43, 1255-1260. [CrossRef] [PubMed]

26. Xu, J.G.; Liu, T.; Hu, Q.P.; Cao, X.M. Chemical composition, antibacterial properties and mechanism of action of essential oil from clove buds against Staphylococcus aureus. Molecules 2016, 21, 1194. [CrossRef]

27. Panizzi, L.; Falmini, G.; Cioni, P.L.; Morelli, I. Composition and antimicrobial properties of essential oil of four Mediterranean Lamiaceae. J. Ethnopharm. 1993, 39, 167-170. [CrossRef]

28. Rana, I.S.; Rana, A.S.; Rajak, R.C. Evaluation of antifungal activity in essential oil of the Syzygium aromaticum (L.) by extraction, purification and analysis of its main component eugenol. Braz. J. Microbiol. 2011, 42, 1269-1277. [CrossRef] [PubMed]

29. Nunez, L.; D'aquino, M.; Chirife, J. Antifungal properties of clove oil (Eugenia caryophylata) in sugar solution. Braz. J. Microbiol. 2001, 32, 123-126. [CrossRef]

30. Ahmad, N.; Alam, M.K.; Shehbaz, A.; Khan, A.; Mannan, A.; Rashid, H.S.; Bisht, B.; Owais, M. Antimicrobial activity of clove oil and its potential in the treatment of vaginal candidiasis. J. Drug Target. 2005, 13, 555-561. [CrossRef] [PubMed]

31. Pinto, E.; Vale-Silva, L.; Cavaleiro, C.; Salgueiro, L. Antifungal activity of the clove essential oil from Syzygium aromaticum on Candida, Aspergillus and dermatophyte species. J. Med. Microbiol. 2009, 58, 1454-1462. [CrossRef]

32. Chami, N.; Chami, F.; Bennis, S.; Trouillas, J.; Remmal, A. Antifungal treatment with carvacrol and eugenol of oral candidiasis in immunosuppressed rats. Braz. J. Infect. Dis. 2004, 8, 217-226. [CrossRef] [PubMed]

33. Chee, H.Y.; Lee, M.H. Antifungal activity of clove essential oil and its volatile vapour against dermatophytic fungi. Mycobiology 2007, 35, 241-243. [CrossRef] [PubMed]

34. Jain, S.K.; Agrawal, S.C. Fungistatic activity of some perfumes against otomycotic pathogens. Mycoses 2002, 45, 88-90. [CrossRef] [PubMed]

35. Gutierrez, J.; Barry-Ryan, C.; Bourke, P. Antimicrobial activity of plant essential oils using food model media, efficacy, synergistic potential and interactions with food components. Food Microbiol. 2009, 26, 142-150. [CrossRef]

36. Moreira, M.R.; Ponce, A.G.; Del Valle, C.E.; Roura, S.I. Effects of clove and tea tree oils on Escherichia coli O157:H7 in blanched spinach and minced cooked beef. J. Food Process. Preserv. 2007, 31, 379-391. [CrossRef]

37. Aguilar-Gonzalez, A.E.; Palou, E.; Lopez-Malo, A. Antifungal activity of essential oils of clove (Syzygium aromaticum) and/or mustard (Brassica nigra) in vapor phase against gray mold (Botrytis cinerea) in strawberries. Innov. Food Sci. Emerg. Technol. 2015, 32, 181-185. [CrossRef]

38. Lindsay, D.; Brözel, V.S.; von Holy, A. Spore formation in Bacillus subtilis biofilms. J. Food Protect. 2005, 68, 860-865. [CrossRef]

39. Kalemba, D.; Kunicka, A. Antibacterial and antifungal properties of essential oils. Curr. Med. Chem. 2003, 10, 813-829. [CrossRef]

40. Kunicka-Styczyńska, A.; Tyfa, A.; Laskowski, D.; Plucińska, A.; Rajkowska, K.; Kowal, K. Clove Oil (Syzygium aromaticum L.) Activity Against Alicyclobacillus acidoterrestris Biofilm on Technical Surfaces. Molecules 2020, 25, 3334. [CrossRef]

41. Li, T.; Wang, D.; Liu, N.; Ma, Y.; Ding, T.; Mei, Y.; Li, J. Inhibition of Quorum Sensing-Controlled Virulence Factors and Biofilm Formation in Pseudomonas fluorescens by Cinnamaldehyde. Int. J. Food Microbiol. 2018, 269, 98-106. [CrossRef] 
42. Kubesová, A.; Šalplachta, J.; Horká, M.; Růžička, F.; Šlais, K. Candida "Psilosis"—Electromigration Techniques and MALDI-TOF Mass Spectrometry for Phenotypical Discrimination. Analyst 2012, 137, 1937-1943. [CrossRef] [PubMed]

43. Rams, T.E.; Sautter, J.D.; Getreu, A.; van Winkelhoff, A.J. Phenotypic Identification of Porphyromonas Gingivalis Validated with Matrix-Assisted Laser Desorption/Ionization Time-of-Flight Mass Spectrometry. Microb. Pathog. 2016, 94, 112-116. [CrossRef] [PubMed]

44. Kačániová, M.; Terentjeva, M.; Galovičová, L.; Ivanišová, E.; Štefániková, J.; Valková, V.; Borotová, P.; Kowalczewski, P.Ł.; Kunová, S.; Felšöciová, S.; et al. Biological Activity and Antibiofilm Molecular Profile of Citrus aurantium Essential Oil and Its Application in a Food Model. Molecules 2020, 25, 3956. [CrossRef]

45. Kačániová, M.; Galovičová, L.; Ivanišová, E.; Vukovic, N.L.; Štefániková, J.; Valková, V.; Borotová, P.; Žiarovská, J.; Terentjeva, M.; Felšöciová, S.; et al. Antioxidant, Antimicrobial and Antibiofilm Activity of Coriander (Coriandrum Sativum L.) Essential Oil for Its Application in Foods. Foods 2020, 9, 282. [CrossRef] [PubMed]

46. Adams, R.P. Identification of Essential Oil Components by Gas Chromatography/Mass Spectrometry; Allured Publishing Corporation: Carol Stream, IL, USA, 2007; ISBN 978-1-93233-11-4.

47. Van Den Dool, H.; Kratz, P.D. A Generalization of the Retention Index System Including Linear Temperature Programmed Gas-Liquid Partition Chromatography. J. Chromatogr. A 1963, 11, 463-471. [CrossRef]

48. Dao, T.; Bensoussan, M.; Gervais, P.; Dantigny, P. Inactivation of Conidia of Penicillium chrysogenum, P. digitatum and P. italicum by Ethanol Solutions and Vapours. Int. J. Food Microbiol. 2008, 122, 68-73. [CrossRef]

49. Talibi, I.; Askarne, L.; Boubaker, H.; Boudyach, E.H.; Msanda, F.; Saadi, B.; Aoumar, A.A.B. Antifungal activity of some Moroccan plants against Geotrichum candidum, the causal agent of postharvest citrus sour rot. Crop Prot. 2013, 35, 41-46. [CrossRef]

50. Aman, M.; Rai, V.R. Antifungal activity of fungicides and plant extracts against yellow sigatoka disease causing Mycosphaerella musicola. Curr. Res. Environ. Appl. Mycol. 2015, 5, 277-284. [CrossRef] 